\title{
Studies on $\beta$-Glucuronidase
}

\section{THE PURIFICATION AND PROPERTIES OF OX-LIVER $\beta$-GLUCURONIDASE}

\author{
BY EVELYN E. B. SMITH* AND G. T. MILLS \\ Biochemistry Department, University of Glasgow
}

(Received 8 July 1952)

While a fairly extensive characterization of the preparation and properties of ox-spleen $\beta$-glucuronidase has been recorded (Fishman, 1939 $a, b$; Graham, 1946; Mills, 1948; Mills, Paul \& Smith, 1949; Bernfeld \& Fishman, 1950a; Mills, Paul \& Smith, 1953), the available data for liver glucuronidase is confined to the work of Sarkar \& Sumner (1950). These authors, using low-temperature dioxan fractionation for the purification of ox-liver $\beta$ glucuronidase, achieved a 6000 -fold purification of the enzyme. Their method of expressing purity, however, is based on an initial expression of activity per gram of fresh tissue, this being compared with a final activity in terms of mg. dry weight of enzyme. It is more accurate to enumerate both values in terms of a common factor, namely protein nitrogen, in which case a 900 -fold purification was achieved. By a combination of metallo-protein interactions, organic solvent precipitation and ammonium sulphate fractionation it has been found possible, in the present work, to achieve a purification of ox-liver $\beta$-glucuronidase equivalent to that obtained by Sarkar \& Sumner (1950). A study of the properties of the purified material does not support the observation of Sarkar \& Sumner (1950) that the $\beta$-glucuronidase of ox liver is a single enzyme with a single $\mathrm{pH}$ optimum at $\mathrm{pH} 4.5$ in acetate buffer, and data are presented to show that the liver enzyme is complex and analogous in many respects to that reported by Mills (1948) and Mills et al. (1953) for ox-spleen $\beta$-glucuronidase. Preliminary reports of this work have already appeared (Smith, 1951; Mills \& Smith, 1952).

\section{METHODS}

Assay of $\beta$-glucuronidase preparations. Phenolphthalein $\beta$-D-glucuronide, prepared biosynthetically by the method of Talalay, Fishman \& Huggins (1946), was used as substrate, and the method of assay was that described by Mills et al. (1953). The unit of enzyme activity is that which liberates $1 \mu \mathrm{g}$. phenolphthalein in $1 \mathrm{hr}$. from $1 \mathrm{~mm}$-phenolphthalein glucuronide at $\mathrm{pH} 4.5$ and $38^{\circ}$.

When studying inhibitory substances, the enzyme digests were made up to contain $0.5 \mathrm{ml}$. buffer solution, $0.2 \mathrm{ml}$. enzyme solution, $0.1 \mathrm{ml}$. water or inhibitor solution and $0.2 \mathrm{ml}$. substrate solution.

* Carnegie Research Scholar.
Unless otherwise stated, the following buffers were employed: for the $\mathrm{pH}$ range 3.4-6.0, 0.2 M-acetate buffers, and for the $\mathrm{pH}$ range $6 \cdot 0-7 \cdot 0$, the veronal-acetate buffers of Michaelis (1931).

Filter-paper electrophoresis. This was carried out by the method of Mills \& Smith (1951).

pH measurements. These were made with a glass electrode and either a Muirhead, Tinsley or Marconi pH meter.

Protein N. This was estimated by the method of Ma \& Zuazaga (1942), using the Markham (1942) distillation unit.

\section{EXPERIMENTAL AND RESULTS}

A recent publication of Cohn et al. (1950) on the use of the interactions of different proteins with bivalent cations to separate the protein components of human plasma, suggested the possibility of using such metallo-protein complexes in the purification of $\beta$-glucuronidase. The following purification scheme has been devised, taking as starting material the stage $C$ fraction described by Mills (1948) in studies on ox-spleen $\beta$-glucuronidase.

Finely minced ox liver was extracted twice with 2 vol. acetone and the filter cake dried in air at room temperature. The powder so obtained was extracted with water, the extract adjusted to $\mathrm{pH} 5 \cdot 0$ with acetic acid, buffered with acetate buffer and autolysed at $38^{\circ}$ for $4 \mathrm{hr}$. The voluminous precipitate so formed was removed in the Sharples centrifuge and solid $\left(\mathrm{NH}_{4}\right)_{2} \mathrm{SO}_{4}$ stirred into the solution to $60 \%$ saturation, followed by equilibration at $0^{\circ}$ for $18 \mathrm{hr}$. The precipitate was then removed by filtration, using Standard Super-Cel (Celite 519 A, Johns-Manville Corporation), the filter cake extracted with water and the extract dialysed, this extract constituting the stage C of Mills's (1948) original purification.

Further purification can be conveniently divided into three stages.

Stage 1. Initial treatment of the Stage C solution with zinc acetate solution results in the precipitation of a large percentage of inactive protein. If this is removed by centrifugation, glucuronidase can be precipitated completely from the supernatant by the addition of acetone to a final con. centration of $20 \%$. This is in contrast to the higher value of $\mathbf{4 5} \%$ acetone required for precipitation of the enzyme in the absence of $\mathrm{Zn}^{2+}$. Elution of the precipitated material with a $15 \%$ acetone solution containing $\mathrm{Ba}^{2+}$ results in a selective extraction of $\beta$-glucuronidase yielding the so-called ' barium eluate'. The procedure is represented in Fig. 1. The percentage distribution of the enzyme obtained by the above fractionation is shown in Table 1 . 
The success of stage 1 is dependent on a number of factors, control of which is important for reproducibility of results. These are: (1) The initial ratio of enzyme activity to protein concentration in the stage $\mathrm{C}$ solution is important, and the solution should be adjusted to a value of 2000-4000 units of activity/mg. protein $\mathrm{N}$ to avoid undue loss of enzyme in the initial zinc precipitation. (2) Strict temperature control is essential throughout as small variations in temperature may lead to critical disturbances in the system. A temperature of
$\left(\mathrm{NH}_{4}\right)_{2} \mathrm{SO}_{4}$ to $60 \%$ saturation. Celite $519 \mathrm{~A}(2 \%$, w/v), was added to adsorb the enzyme which, after filtration, was eluted from the Celite with four $25 \mathrm{ml}$. portions of $1.8 \mathrm{M}$ $\left(\mathrm{NH}_{4}\right)_{2} \mathrm{SO}_{4}$ solution. The filter cake was further extracted with similar portions of $1.6,1.4$ and $1.2 \mathrm{M}-\left(\mathrm{NH}_{4}\right)_{2} \mathrm{SO}_{4}$ solutions. The combined eluates of each individual fraction were adjusted to a final concentration of $3 \mathrm{M}$ with solid $\left(\mathrm{NH}_{4}\right)_{2} \mathrm{SO}_{4}$, the precipitate spun off at $0^{\circ}$ and dissolved in the minimum volume of water (generally $3 \mathrm{ml}$.).

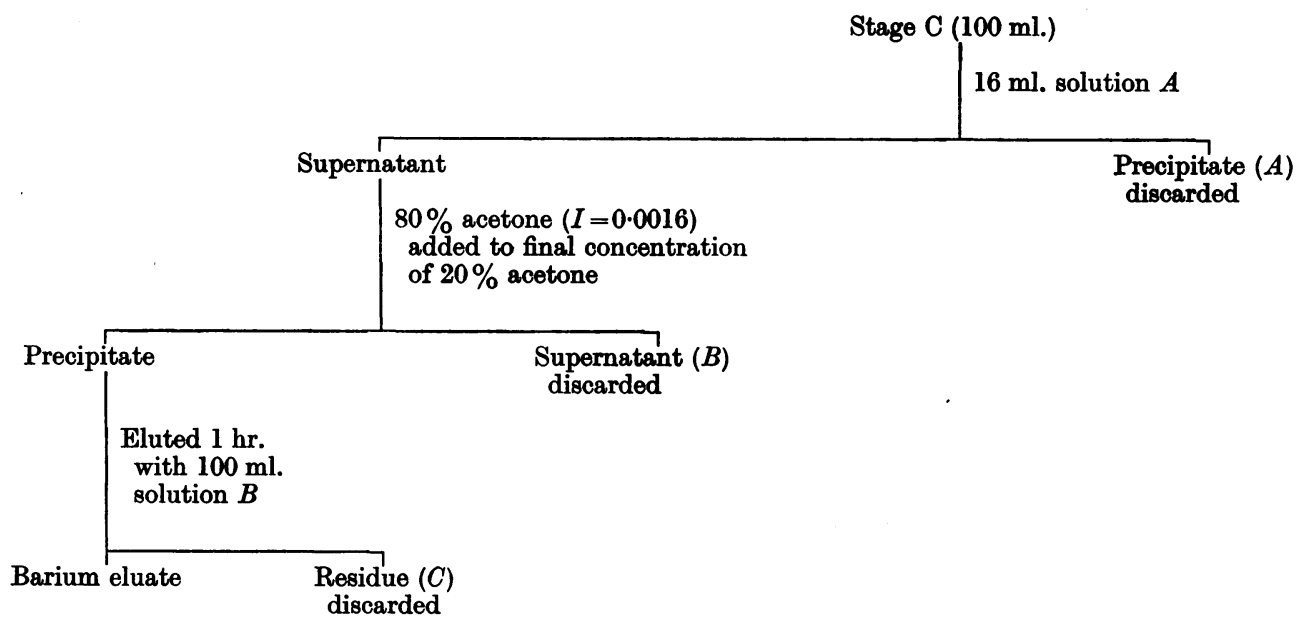

Solution $A: 5.48 \mathrm{~g}$. zinc acetate dihydrate per $100 \mathrm{ml}$. water.

Solution $B$ : per $100 \mathrm{ml}$. water: $0.26 \mathrm{~g}$. barium acetate, $2 \mathrm{ml}$. M-sodium acetate, $0.73 \mathrm{ml}$. M-acetic acid, $15 \mathrm{ml}$. acetone. pH 5.5-5.6.

Fig. 1. Scheme of stage 1 of purification of ox-liver $\beta$-glucuronidase.

$0^{\circ}$ was employed throughout stage 1 of purification. (3) The presence of $\mathrm{Ba}^{2+}$ allows the precipitated enzyme to be eluted within the acetone range of $15-20 \%$ to give the barium eluate. A complete recovery of glucuronidase was not effected, some $17 \%$ remaining in the residue. This was dependent on the time period of elution. Extraction for $1 \mathrm{hr}$. allows the maximum separation of enzyme relative to the amount of inactive protein simultaneously eluted. With longer extraction periods almost all of the enzyme can be recovered but with a decrease in purity.

Table 1. Percentage distribution of ox-liver $\beta$-glucuronidase during purification

$\begin{array}{cc}\text { Stage 1 } & \begin{array}{c}\text { Distribution } \\ \text { of enzyme } \\ (\%)\end{array} \\ \text { Barium eluate } & 60 \\ \text { Precipitate }(A) & 15 \\ \text { Supernatant }(B) & 0 \\ \text { Residue }(C) & 17 \\ \text { Stage 2 (from barium eluate) } & \\ 1 \cdot 8 \mathrm{M}-\left(\mathrm{NH}_{4}\right)_{2} \mathrm{SO}_{4} \text { fraction } & 43 \\ 1.6 \mathrm{M}-\left(\mathrm{NH}_{4}\right)_{2} \mathrm{SO}_{4} \text { fraction } & 30 \\ 1.4 \mathrm{M}-\left(\mathrm{NH}_{4}\right)_{2} \mathrm{SO}_{4} \text { fraction } & 15 \\ 1 \cdot 2 \mathrm{M}-\left(\mathrm{NH}_{4}\right)_{2} \mathrm{SO}_{4} \text { fraction } & 2 \\ \end{array}$

Stage 2. Following dialysis of the barium eluate at $0^{\circ}$, glucuronidase was precipitated from solution by adding solid
$90 \%$ of the total glucuronidase present in the barium eluate can be recovered by the above procedure with the percentage distribution shown in Table 1 .

Most of the enzyme activity was associated with the $1.8 \mathrm{~m}$ eluate, but this was discarded in view of its high content of inactive protein. The 1.6 and $1.4 \mathrm{M}$ fractions were highly active (80000-100000 units of activity per ml.), and were associated with low protein contents.

Stage 3. A large percentage of $\beta$-glucuronidase was precipitated from solution on dialysis of the combined 1.6 and $1.4 \mathrm{M}-\left(\mathrm{NH}_{4}\right)_{2} \mathrm{SO}_{4}$ fractions obtained in stage 2 . An investigation of the effects of controlled dialysis on the purification of the enzyme was considered and two techniques were employed.

(a) A fairly exhaustive dialysis was required to precipitate the enzyme from solution, and inactive material could be removed initially by a short dialysis period ( $24 \mathrm{hr}$.). A more prolonged dialysis of the supernatant (3-4 days) against several changes of distilled water precipitated the enzyme which, after centrifugation and elution with $3 \mathrm{ml} .1 \% \mathrm{NaCl}$ solution, yielded a glucuronidase preparation containing 200000 units of activity per $\mathrm{mg}$. protein $\mathrm{N}$.

(b) Alternatively, the glucuronidase was first precipitated from solution by a 3- to 4-day dialysis against distilled water, followed by extraction of the centrifuged precipitate with 6-8 ml. of a $1 \% \mathrm{NaCl}$ solution. Dialysis of the extract reprecipitated the enzyme, which on a further elution with $3 \mathrm{ml}$. of $1 \% \mathrm{NaCl}$ solution gave an enzyme preparation equivalent in purity to that obtained by method $(a)$. 
Table 2. Purification of ox-liver $\beta$-glucuronidase

\begin{tabular}{|c|c|c|c|c|c|}
\hline & Units*/ml. & $\begin{array}{c}\text { Volume } \\
\text { (ml.) }\end{array}$ & $\begin{array}{l}\text { Total } \\
\text { units* }\end{array}$ & Purity $\dagger$ & $\begin{array}{l}\text { Yield } \\
(\%)\end{array}$ \\
\hline Liver mince & 6000 & - & - & 240 & - \\
\hline Stage $C$ & 20000 & 100 & $2 \times 10^{6}$ & 2500 & 100 \\
\hline Barium eluate & 12000 & 100 & $1.2 \times 10^{6}$ & 14000 & 60 \\
\hline $1.6 \mathrm{M}-\left(\mathrm{NH}_{4}\right)_{2} \mathrm{SO}_{4}$ fraction & 80000 & 4 & $32 \times 10^{4}$ & - & 16 \\
\hline $1.4 \mathrm{M}-\left(\mathrm{NH}_{4}\right)_{2} \mathrm{SO}_{4}$ fraction & 60000 & 3 & $18 \times 10^{4}$ & - & 9 \\
\hline Stage 3 purified material & 20000 & 5 & $10 \times 10^{4}$ & 200000 & $\mathbf{5}$ \\
\hline
\end{tabular}

$*$ Unit of activity $=1 \mu \mathrm{g}$. phenolphthalein liberated/hr. under the conditions specified in Methods section.

$\dagger$ Purity expressed in terms of activity/mg. protein N.

A temperature of $0^{\circ}$ or less must be maintained throughout dialysis. When dialysis was carried out against running water $\left(12^{\circ}\right)$, rapid denaturation occurred with an overall loss in enzyme activity of $35 \%$ over a period of $8 \mathrm{hr}$., whereas losses were negligible at $0^{\circ}$. A short period of extraction with $1 \%$ sodium chloride solution ( $15 \mathrm{~min}$.) preferentially elutes the enzyme from the precipitate obtained on dialysis; with longer extraction periods, higher yields of enzyme are obtained at the expense of purity. Quantitative details of the purification are shown in Table 2. Starting from minced ox liver containing 240 units of activity per mg. protein $\mathrm{N}$, an overall purification of $\mathbf{8 0 0}$-fold is obtained with $5 \%$ recovery of the enzyme.

\section{Properties of the purified material}

The purified $\beta$-glucuronidase is a pale, strawcoloured solution. Solutions containing 200000 units of activity per mg. protein $\mathrm{N}$ appeared to be relatively unstable, and when stored at $0^{\circ}$ for 2 days a $25 \%$ loss in activity was apparent. After this there was no further loss in activity for at least 2-3 weeks at $0^{\circ}$, and the properties of the enzyme were accordingly obtained from this more stable material ( 150000 units per mg. protein $\mathrm{N}$ ).

Isoelectric point of ox-liver $\beta$-glucuronidase. The isoelectric point of purified ox-liver $\beta$-glucuronidase was determined by estimating the mobility of the enzyme on filter-paper strips at various $\mathrm{pH}$ values from $4 \cdot 0$ to $8 \cdot 0$. Crystalline bovine serum albumin (Armour) was examined at the same time to determine the accuracy of the method. The results of this experiment are shown in Fig. 2, which shows that the isoelectric point of $\beta$-glucuronidase is at $\mathrm{pH} 4 \cdot 85$ and that for crystalline bovine serum albumin is at $\mathrm{pH} 4 \cdot 65$. This latter value corresponds well with the accepted value of $\mathrm{pH} 4 \cdot 7$.

Amino-acid constitution of purified ox-liver $\beta$ glucuronidase. To $2 \mathrm{ml}$. enzyme solution containing $0.22 \mathrm{mg}$. protein $\mathrm{N}$ (purity $=150000$ enzyme units/ mg. protein $N$ ) concentrated hydrochloric acid was added to a final concentration of $6 \mathrm{~N}$. The enzyme was hydrolysed by heating for $18 \mathrm{hr}$. at $110^{\circ}$ in a sealed tube. Hydrochloric acid was evaporated off in vacuo over solid potassium hydroxide and the residue dissolved in $\mathbf{0 . 2} \mathrm{ml}$. distilled water. A twodimensional chromatogram was obtained with $50 \mu \mathrm{l}$. of the extract on Whatman no. 1 paper, using as solvents: (a) $n$-butanol-acetic acid $(40 \% n$ butanol, $10 \%$ glacial acetic acid and $50 \%$ water by volume) and (b) phenol. The result showed the presence of seventeen amino-acids in the purified $\beta$-glucuronidase preparation with no unusual features.

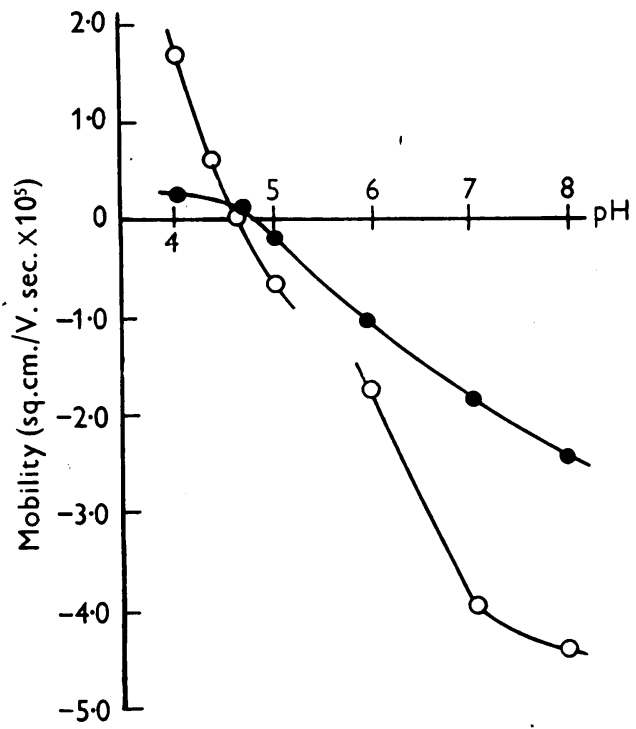

Fig. 2. Electrophoretic migration of purified ox-liver $\beta$-glucuronidase (-0) and crystalline bovine serum albumin (Armour) (O-O) on filter-paper strips. Acetate buffers, $\mathrm{pH} 4-5$, and phosphate buffers, $\mathrm{pH} 6-8$. $I=0 \cdot 05$.

pH-Activity curve. A typical pH-activity curve for the purified enzyme is shown in Fig. 3. While the enzyme appears to be stable over a wide $\mathrm{pH}$ range, the presence of a number of well-defined optima in a preparation of such high purity is suggestive of the complexity of the system. The $\mathrm{pH}$-activity curve in the region of $\mathrm{pH} 5 \cdot 5-7 \cdot 0$ was re-investigated using phosphate-citrate buffer and the presence of an optimum at $\mathrm{pH} 6.3$ confirmed. Although the 
activity curve presented may be considered representative of the purified enzyme, different preparations showed individual variation in the proportionality of activity at the $\mathrm{pH}$ maxima. It is interesting to note that all highly purified enzyme

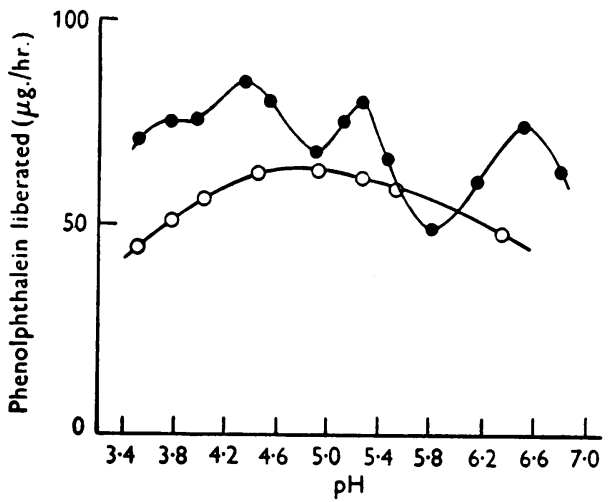

Fig. 3. (-), pH-activity curve of purified ox-liver $\beta$ glucuronidase. Purity $=150000$ units per mg. protein N. (O-O), pH-activity curve of above preparation after standing at $0^{\circ}$ for 3 weeks. These curves are not to be related quantitatively.

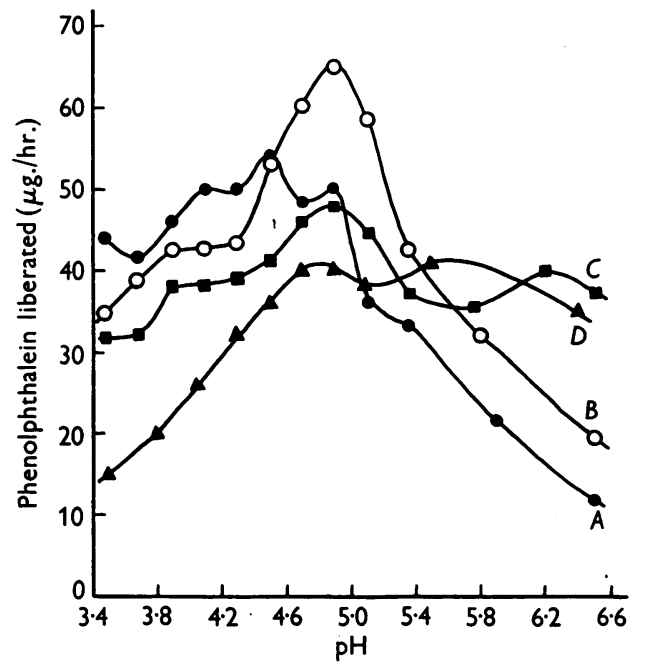

Fig. 4. $\mathrm{pH}$-Activity curves of purified ox-liver $\beta$-glucuronidase at various concentrations of phenolphthalein glucuronide. $A, 0.25 \mathrm{~mm} ; B, 0.5 \mathrm{~mm} ; C, 1.0 \mathrm{~mm} ; D$, 4.0 mM.

preparations when allowed to stand for any length of time ( 3 weeks at $0^{\circ}$ ) showed a gradual change in the $\mathrm{pH}$-activity curve from that of well defined optima to the plateau-sheped curve shown in Fig. 3. The quantitative relationship between these two curves has not been investigated.

Fig. 4 shows the variation in shape of the pH. activity curve of a preparation of purified ox-liver $\beta$-glucuronidase assayed at different substrate concentrations. These changes in $\mathrm{pH}$-activity curve with varying substrate concentration, which are analogous to those already reported for ox-spleen $\beta$-glucuronidase (Mills et al. 1953), indicate that in all probability we are again dealing with a mixture of $\beta$-glucuronidases with different $\mathrm{pH}$ optima and differing substrate affinity.

The effect of deoxyribonucleic acid (DNA) and other compounds on the activity of ox-liver $\beta$-glucuranidase

Bernfeld \& Fishman (1950b) claim to have shown that calf-spleen $\beta$-glucuronidase preparations contain a thermostable coenzyme which dissociates from the parent molecule on dilution. While the nature of this coenzyme is still unidentified, it has been shown by the above authors that the action of this coenzyme may be duplicated by adding deoxyribonucleic acid (DNA) to the system.

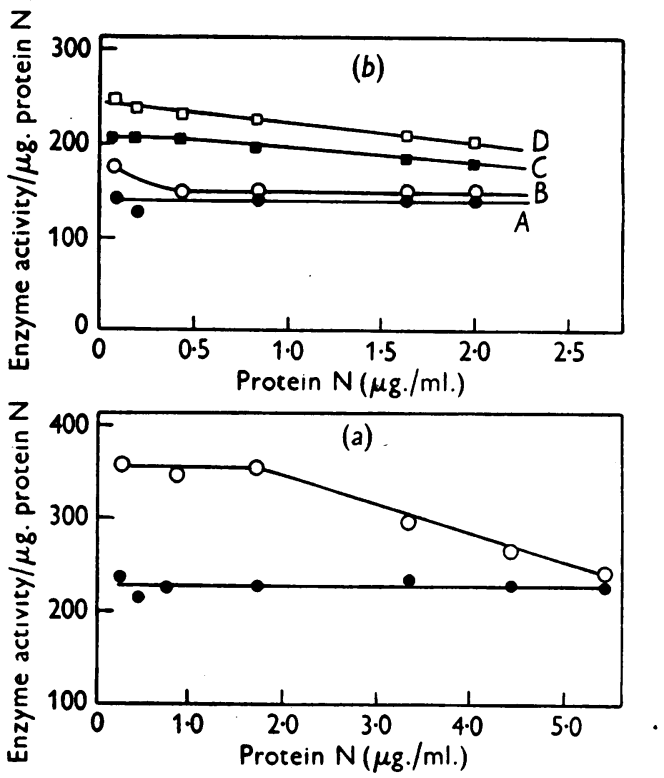

Fig. 5. (a) Effect of dilution on the enzyme activity to protein ratio $(E / P)$ in the absence (-O) and the presence $(\mathrm{O}-\mathrm{O})$ of $0.06 \%$ DNA. Enzyme assayed at pH 4.5. (b) Effect of dilution on the enzyme activity to protein ratio $(E / P): A$, in the absence and $B$, in the presence of $0.2 \%$ starch; $C, 0.1 \%$ gum acacia and $D$, $0.05 \%$ crystalline bovine serum albumin (Armour). Enzyme assayed at pH 4.5.

Studies on purified ox-liver $\beta$-glucuronidase in the present work, however, do not indicate that DNA functions as a coenzyme-like substance. Enzyme activity was determined at varying dilutions in the presence and absence of DNA (final concentration, $0.06 \%$; prepared from calf thymus by the method of Mirsky \& Pollister, 1946). If glucuronidase 
activity is dependent on a coenzyme dissociating on dilution, the ratio of enzyme activity to protein concentration $(E / P)$ will drop greatly with dilution as observed by Bernfeld \& Fishman (1950b) for calfspleen $\beta$-glucuronidase, and a plot of the $E / P$ ratio against protein concentration should take the form of an S-shaped curve in accordance with the dissociation expression:

$$
\frac{(P-E)(C-E)}{E}=K
$$

where $P=$ total protein, $C=$ total coenzyme, $E=$ active enzyme, $P / C$ constant and $K$ a constant. In the presence of DNA, the activity of $\beta$-glucuronidase should be proportional to the protein concentration. Such a plot is presented in Fig. $5 a$ for purified liver $\beta$-glucuronidese assayed at $\mathrm{pH} 4 \cdot 5$. Fig. $5 a$ shows that a plot of enzyme activity to protein concentration is linear at all dilutions down to a protein concentration of $0.05 \mu \mathrm{g}$. protein $\mathrm{N}$ per ml. Such results provide no indication of a coenzyme dissociating from the parent molecule at high dilutions.

Added DNA is an effective activator of ox-liver $\beta$-glucuronidase at $\mathrm{pH} 4.5$ (Fig. 5a). It was considered that this activating effect of DNA need not be specific and a number of other high molecular weight compounds were investigated in this respect. Albumin, gum acacia and starch were arbitrarily chosen, and their effects on the assay at $\mathrm{pH} 4.5$ of purified liver $\beta$-glucuronidase at varying dilutions are shown in Fig. $5 b$.

\section{Inhibition of ox-liver $\beta$-glucuronidase by $D N A$, suramin and alginic acid}

While DNA is an effective activator of ox-liver $\beta$ glucuronidase at $\mathrm{pH} 4.5$ (acetate buffer), a phenomenon of equal interest is the inhibitory action of DNA at lower $\mathrm{pH}$ values. A typical $\mathrm{pH}$-activity curve in the presence of $0.06 \% \mathrm{DNA}$ is shown in Fig. 6. Sharp inhibition was apparent below $\mathrm{pH} 4 \cdot 2$ and activation above this $\mathrm{pH}$. The shape of the curve altered to give a single optimum at $\mathrm{pH} 4 \cdot 5-5$ with a rise in activity in this region.

An interesting comparison may be made between the effect of added DNA and the action of suramin on certain enzymes. Wills \& Wormall (1950) and Wills (1952) have shown that suramin, a polysulphonic acid, inhibits many enzymes on the acid side of their isoelectric points. When percentage inhibition was plotted against $\mathrm{pH}$ in such instances, a sharp drop was evident in the inhibition-pH curve, $50 \%$ inhibition occurring at or about the isoelectric point of the enzyme. A similar sharp drop is evident in the inhibition-pH curve of liver glucuronidase in the presence of DNA, and Fig. 7 compares the effect of both DNA and suramin on liver glucuronidase activity in terms of an inhibition-pH graph. Although DNA and suramin are dissimilar in the $\mathrm{pH}$ range over which inhibition occurs, their effects are none the less comparable in many respects, and suramin has also been shown to exert a similar activating effect to that of DNA in the higher pH range (Fig. 6).

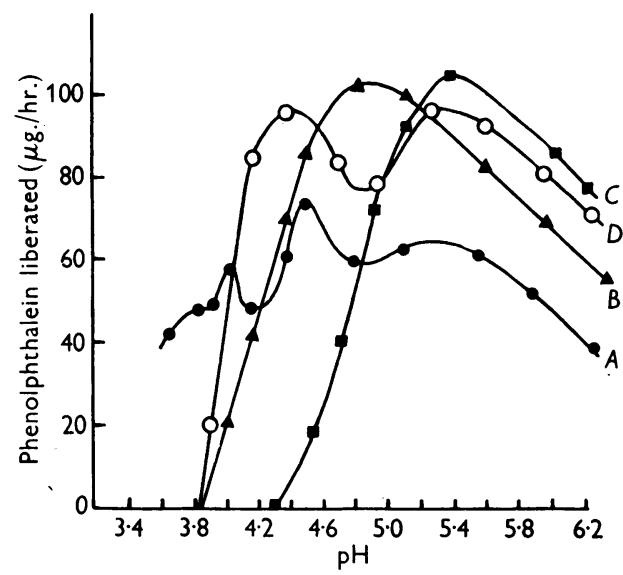

Fig. 6. Effect of $0.06 \%$ DNA, $10^{-3} \mathrm{M}$-suramin and $0.1 \mathrm{M}$ phthalate buffers on the $\mathrm{pH}$-activity curve of purified oxliver $\beta$-glucuronidase: $A$, control in $0.1 \mathrm{~m}$-acetate buffer; $B$, plus $0.06 \%$ DNA; $C$, plus $10^{-8} \mathrm{M}$-suramin; $D$, assays in $0 \cdot 1$ M-phthalate buffers.

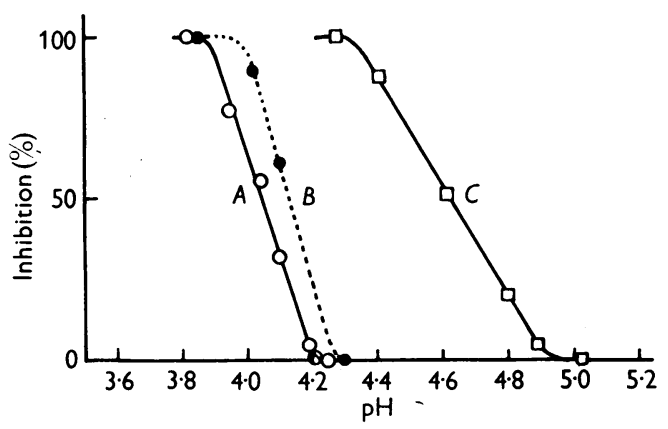

Fig. 7. Effect of $\mathrm{pH}$ on the inhibition of ox-liver $\beta$-glucuronidase by: $A, 0.06 \% \mathrm{DNA} ; B, 0.06 \%$ alginic acid and $C, 10^{-8} \mathrm{M}$-suramin.

Alginic acid is another high molecular weight compound whose inhibition of glucuronidase depends on $\mathrm{pH}$, and the inhibition-pH curve for this compound is also shown in Fig. 7.

\section{Effects of organic acids on ox-liver $\beta$-glucuronidase activity}

Morrow, Carroll \& Greenspan (1951), in a study of the glucuronidase activity of inbred mice, referred to the single $\mathrm{pH}$ optimum obtained in the assay of mouse-kidney homogenates. A most surprising feature of the activity curve was the total absence of activity below $\mathrm{pH} 3 \cdot 8$, the curve rising sharply from 
Table 3. The effect of structurally related organic acids on ox-liver $\beta$-glucuronidase activity

(All compounds assayed at a final concentration of $10^{-2} \mathrm{M}$. Activity determined at $\mathrm{pH} \mathrm{3.4,4.5}$ and $5 \cdot 2$ (0.2 M-acetate buffers). Enzyme purity $=170000$ units activity/mg. protein N.)

\begin{tabular}{|c|c|c|c|}
\hline mg. protein N.) & Acti & $\begin{array}{c}+ \text { ) or in } \\
(\%)\end{array}$ & $(-)$ \\
\hline$K_{a}^{*}$ & pH 3.4 & $\mathrm{pH} 4.5$ & $\mathrm{pH} 5 \cdot 2$ \\
\hline $6.5 \times 10^{-5}$ & +37 & +6 & +17 \\
\hline - & -100 & -4 & +9 \\
\hline $9 \cdot 1 \times 10^{-5}$ & -9 & 0 & 0 \\
\hline $5.0 \times 10^{-2}$ & -100 & $\begin{array}{r}5 \\
+5\end{array}$ & +26 \\
\hline $3.3 \times 10^{-5}$ & & 0 & 0 \\
\hline $1.3 \times 10^{-8}$ & -100 & -85 & -76 \\
\hline & -29 & -40 & -19 \\
\hline 1st. $\mathrm{H} 1.3 \times 10^{-3}$ & -100 & +50 & +47 \\
\hline - & -23 & +50 & +45 \\
\hline - & -89 & $\begin{array}{r}+48 \\
\end{array}$ & +40 \\
\hline - & -100 & +57 & +41 \\
\hline - & +56 & +25 & +28 \\
\hline - & -100 & +55 & +93 \\
\hline - & -100 & -4 & +8 \\
\hline - & 0 & 0 & 0 \\
\hline - & o & 0 & 0 \\
\hline - & +62 & +14 & -70 \\
\hline - & +47 & $\begin{array}{l}+10 \\
+10\end{array}$ & -100 \\
\hline - & -100 & -13 & +19 \\
\hline
\end{tabular}

* From Dictionary of Organic Compounds (1943). Ed. by Heilbron, I. H. and Bunbury, H. M. London: Eyre and Spottiswoode.

zero activity at this $\mathrm{pH}$ to the optimum around $\mathrm{pH} 4 \cdot 5$. It was noted that phthalate-hydrochloric acid and phthalate-sodium hydroxide buffers were used by Morrow et al. (1951), and it was considered that the lack of activity in the lower $\mathrm{pH}$ range was probably due to specific inhibition of enzyme

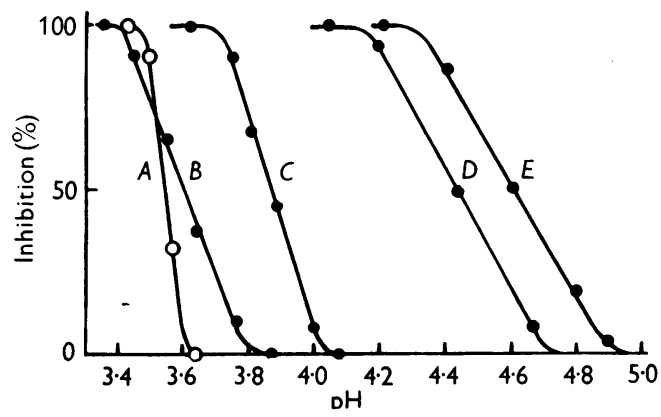

Fig. 8. Effect of $\mathrm{pH}$ on the inhibition of ox-liver $\beta$-glucuronidase by : $A, 10^{-2} \mathrm{M}$-benzoic acid 3:5-disulphonic acid; $B, 10^{-2} \mathrm{M}-2: 5$-dihydroxyterephthalic acid; $C, 10^{-2} \mathrm{M}$ phthalic acid; $D, 2 \times 10^{-3} \mathrm{M}-2-n a p h t h o l-3: 6$-disulphonic acid; $E, 10^{-3} \mathrm{M}$-suramin.

activity by phthalic acid. This was confirmed by assaying the purified enzyme in both phthalate and acetate buffers. Reference to Fig. 6 shows the marked inhibitory effect of phthalate in the lower $\mathrm{pH}$ range and the considerable activation above pH 4.0. Phthalate increased the activity at the optima at $\mathrm{pH} 4.5$ and $\mathbf{5 . 2}$.
The inhibition of ox-liver $\beta$-glucuronidase activity by a number of structurally related organic compounds was studied. Inhibition was determined at pH 3.4, 4.5 and 5.2 in acetate buffer. All acids were neutralized prior to assay with $\mathrm{N}-\mathrm{NaOH}$. The results are summarized in Table 3.

In Fig. 8 is shown a comparison of the pH. inhibition curves of glucuronidase for a number of the compounds listed in Table 3.

\section{DISCUSSION}

While Sarkar \& Sumner (1950) have suggested that ox-liver $\beta$-glucuronidase is a single enzyme with a single $\mathrm{pH}$ optimum at $4 \cdot 5$, the type of $\mathrm{pH}$-activity curve obtained in the present work using a highly purified enzyme preparation is suggestive of the complexity of the enzyme system. The most interesting feature in this respect is.the observation that all highly purified enzyme preparations when allowed to stand for any length of time (3 weeks) showed a plateau-shaped curve similar to that illustrated by Sarkar \& Sumner (1950) for their purified $\beta$-glucuronidase preparation. The $\mathrm{pH}$ activity curve of an enzyme is the resultant of a number of factors, including enzyme stability, and it might be assumed that the latter factor plays a predominant part in determining the activity curve of purified glucuronidase preparations. Such preparations have low-protein contents, and the enzyme may be susceptible to $\mathrm{pH}$ changes in the absence of the protective protein. This possibility receives support from the observation that less pure 
enzyme preparations, characterized by a lower activity/protein ratio, maintain the well defined optima on standing for periods of several weeks.

No evidence is forthcoming from the present work to show that ox-liver $\beta$-glucuronidase contains a coenzyme dissociating from the molecule on dilution. The discrepancy between the present findings and those of Bernfeld \& Fishman (1950b) for calf-spleen $\beta$-glucuronidase may be due either to the widely differing methods of purification employed, or to the effect of dilution on the stability of the enzyme prepared by Bernfeld \& Fishman (1950b). Our investigation of the effects of added DNA on liver glucuronidase activity emphasize the fact that this compound does not act as a coenzyme-like substance. While DNA is an effective activator of liver $\beta$-glucuronidase at $\mathrm{pH} 4 \cdot 5$, as observed by Bernfeld $\&$ Fishman (1950 b), the activating effect at this $\mathrm{pH}$ can be reproduced by a variety of other agents such as albumin, gum acacia and starch. Since the completion of this work, Beyler \& Szego (1952) have also reported the activating effect of albumin on glucuronidase activity.

Wills \& Wormall (1950) and Wills (1952) have shown that many enzymes are inhibited by suramin in acid solution, but not in neutral or alkaline solution, the inhibition falling sharply at or about the isoelectric point of the enzyme. It was suggested by the above authors that suramin does not combine directly with the active centres of such enzymes, but that inactivation involves the combination with, or association of, the sulphonic acid groups of suramin with basic groups lying near, or perhaps on opposite sides of the active centre, with a resultant 'bridge' formation protecting the latter. While ox-liver $\beta$ glucuronidase falls into the group A enzyme classification of Wills \& Wormall (1950), where a slight change of pH, itself without effect on the activity, has a profound effect on the degree of inhibition exerted by suramin, it is obvious that the bridging mechanism proposed for suramin action on such group A enzymes would not appear to be applicable in the case of glucuronidase. In the latter instance, small molecular weight acidic compounds can cause marked inhibition of enzyme activity.

The marked dependence on $\mathrm{pH}$ of inhibition by DNA, alginic acid, phthalic acid, 2:5-dihydroxyterephthalic acid, benzoic acid 3:5-disulphonic acid and 2-naphthol-3:6-disulphonic acid is compared with the suramin inhibition of $\beta$-glucuronidase in Figs. 7 and 8, and the fact that the curves fall sharply from $100 \%$ to zero inhibition over a very. narrow $\mathrm{pH}$ range in all cases suggests that certain reservations should be made when applying the suramin inhibition method to a determination of the isoelectric point of certain enzymes.

The effect on $\beta$-glucuronidase activity of aromatic acids appears to conform to certain well-defined principles, namely: (1) The presence of one acid group on the benzene ring causes activation at all $\mathrm{pH}$ values studied. The sulphonic acid group appears to be more effective in this respect than the less strongly ionized carboxyl group. (2) Introduction of another acid group into the molecule invariably results in inhibition of enzyme activity at $\mathrm{pH} 3 \cdot 4$ concurrent with activation at $\mathrm{pH} 4 \cdot 5$ and 5.2. (3) Introduction of hydroxyl groups into the monoacidic aromatic molecule is specific in effect. Provided the position ortho to the acid group is unsubstituted, the activating effect of the acid decreases progressively with hydroxyl substitution. 3:4-Dihydroxybenzoic acid is without effect on enzyme activity, while 3:4:5-trihydroxybenzoic acid functions as an inhibitor at all $\mathrm{pH}$ values. (4) In all instances, introduction of an hydroxyl constituent ortho to an acidic component results in complete inhibition of enzyme activity at $\mathrm{pH} 3.4$ at the concentration of inhibitors studied $\left(10^{-2} \mathrm{M}\right)$. Direct attachment of the acid group to the benzene nucleus is not an essential feature of this inhibition since 2:5-dihydroxyphenylalanine, where the hydroxyl group is positioned ortho to a side chain containing a terminal acidic grouping, acts in a similar manner.

Inhibition by phenylalanine and tyrosine is of interest in view of their occurrence in vivo. The relative concentrations of both amino-acids required for inhibition are high and, while tyrosine is the more effective in this respect, a concentration of $10^{-3} \mathrm{M}$ is required to effect $10 \%$ inhibition.

From a consideration of the available dissociation constants of the compounds listed in Table 3 , it would appear that the degree of dissociation of any one compound has little relevance to the measure of inhibition or activation at any one $\mathrm{pH}$, and that such effects are dependent more on the specific configuration of the molecule.

\section{SUMMARY}

1. A method has been devised for the purification of ox-liver $\beta$-glucuronidase, using reactions with metallic ions and organic solvents. An 800-fold purification has been achieved by such means, with a $5 \%$ recovery of the enzyme.

2. The pH-activity curve of the purified material shows optima at $4 \cdot 5,5 \cdot 2$ and $6 \cdot 3$, and the possible complexity of the enzyme is indicated.

3. The isoelectric point of purified ox-liver $\beta$ glucuronidase by filter-paper electrophoresis was found to be $\mathrm{pH} \mathrm{4 \cdot 85}$.

4. No evidence is forthcoming from the present work to indicate that ox-liver $\beta$-glucuronidase contains a coenzyme dissociating from the molecule on dilution.

5. Details are given of the inhibition and activation of ox-liver $\beta$-glucuronidase by deoxyribonucleic 
acid, suramin, alginic acid and a number of other organic acids, the exact effect in each case varying with pH.

The expenses of this research were defrayed in part from the Rankin Fund of the University of Glasgow and by a grant from the Carnegie Trust for the Universities of Scotland, which are acknowledged with grateful thanks.

We wish to thank Dr J. Reid and Dr P. Ongley for some of the organic compounds tested, and Dr D. J. Bell for the sample of sodium alginate. We are also indebted to $\mathrm{Dr} G$. Leaf for assistance with the amino-acid chromatography.

\title{
REFERENCES
}

Bernfeld, P. \& Fishman, W. H. (1950a). Arch. Biochem. 27, 475.

Bernfeld, P. \& Fishman, W. H. (1950b). Science, 112, 653.

Beyler, A. L. \& Szego, C. M. (1952). Fed. Proc. 11, 13.

Cohn, E. J., Gurd, R. F. N., Surgenor, D. M., Barnes, B. A., Brown, R. K., Derouaux, R. K., Gillespie, J. M., Kahnt, F. W., Liu, C. H., Mittleman, D., Mouton, R. F., Schmidt, K. \& Uroma, E. (1950). J. Amer. chem. Soc. 72, 465.

Fishman, W. H. (1939a). J. biol. Chem. 127, 367.

Fishman, W. H. (1939b). J. biol. Chem. 131, 225.

Graham, A. F. (1946). Biochem. J. 40, 603.

Ma, T. S. \& Zuazaga, G. (1942). Industr. Engng Chem. (Anal.), 14, 280.

Markham, R. (1942). Biochem. J. 36, 790.

Michaelis, L. (1931). Biochem. Z. 234, 139.

Mills, G. T. (1948). Biochem. J. 43, 125.

Mills, G. T., Paul, J. \& Smith, E. E. B. (1949). 1 lst Int. Congr. Biochem. Abstr. p. 597.
Mills, G. T., Paul, J. \& Smith, E. E. B. (1953). Biochem. J. $53,232$.

Mills, G. T. \& Smith, E. E. B. (1951). Biochem. J. 49, vi.

Mills, G. T. \& Smith, E. E. B. (1952). 2nd Int. Congr. Biochem. Abstr. p. 236.

Mirsky, A. E. \& Pollister, A. W. (1946). J. gen. Physiol. 30, 117.

Morrow, A. G., Carroll, D. M. \& Greenspan, E. M. (1951). $J$.nat. Cancer Inst. 11, 663.

Sarkar, N. K. \& Sumner, J. B. (1950). Arch. Biochem. 27, 453.

Smith, E. E. B. (1951). Biochem. J. 50, viii.

Talalay, P., Fishman, W. H. \& Huggins, C. (1946). J. biol. Chem. 166, 757.

Wills, E. D. (1952). Biochem. J. 50, 421.

Wills, E. D. \& Wormall, A. (1950). Biochem. J. 47, 158.

\section{Unimolecular Films of Polymyxins A, B, D and E at the Air-water Interface}

\author{
By A. V. FEW AND J. H. SCHULMAN \\ Department of Colloid Science, University of Cambridge
}

(Received 14 October 1952)

The polymyxins consist of a group of five watersoluble basic polypeptide antibiotics possessing a specific action against Gram-negative bacteria ; they are produced by many strains of the organism Bacillus polymyxa. Benedict \& Langlykke (1947) first reported the antibacterial properties of cultures of this organism.

Chemical analysis of the hydrolysates of the antibiotics showed that a fatty acid, identified by Wilkinson (1949) as D-6-methyloctan-1-oic acid, was present in all the polymyxins. Amino-acid analyses demonstrated that polymyxin $\mathbf{A}$ contained L-threonine, L- $\alpha \gamma$-diaminobutyric acid and D-leucine (Catch, Jones \& Wilkinson, 1948); polymyxin B contained the above amino-acids with Dphenylalanine in addition (Catch, Jones \& Wilkinson 1949); polymyxin $C$ differed from polymyxin $B$ in not containing $\mathrm{D}$-leucine; polymyxin $\mathrm{D}$ possessed the same amino-acids as polymyxin $A$ but in addition $\mathrm{D}$-serine (Jones, 1948); and polymyxin $\mathrm{E}$ had the same amino-acid composition as polymyxin A, but the intact antibiotics could be readily differentiated by paper chromatography (Jones, 1948).

The chemotherapeutic and pharmacological properties of the five polypeptides were studied by Brownlee, Bushby \& Short (1952) and showed that the polymyxins $A, C$ and $D$ all caused severe proteinuria when administered parenterally in animals and man, this occurring even with the purest samples of the antibiotics. In this respect polymyxins $B$ and $E$ differed considerably since they exhibited far less nephrotoxic action.

Relatively little information has accumulated concerning the physical properties of the entibiotics. Jones $(1948,1949)$ has carried out chromatographic analyses of the antibiotics and has also studied their electrometric titration curves. Bell et al. (1949) have determined the molecular weight of polymyxin $\mathrm{D}$ by an osmometric method.

In the present communication, the investigation is described of the properties of unimolecular films of four of the polymyxins when spread at the air-water 